\title{
Assessment of Municipal Solid Waste As Refuse Derived Fuel in the Cement Industry
}

\author{
Gabroni Sagala $^{\#}$, Gabriel A. Kristanto ${ }^{\#}$, Muhammad A. Kusuma ${ }^{*}$, Syifa Rizki ${ }^{*}$ \\ \# Environmental Engineering Study Program, Civil Engineering Department, Universitas Indonesia, Depok 16424, Indonesia \\ E-mail: gabroni.sagala@gmail.com,ga.kristanto@gmail.com,syifarizki28@gmail.com
}

* PT. Indocement Tunggal Prakarsa.Tbk, Citeureup, Jawa Barat, Indonesia

E-mail: angga.kusuma@Indocement.co.id

\begin{abstract}
In Indonesia, waste processing is a very complicated problem especially in major industries such as the cement industry. Demand for cement in Indonesia is very high and recorded to reach 69.8 million tons in 2015 . Indocement, the 2nd largest cement manufacturer in Indonesia, reported that in 2015 the demand for cement reached 13.32 million tons of clinker and is projected to rise by an average of $\mathbf{2 . 6 1 \%}$ per year. Higher demand for cement results in higher energy required which leads to higher use of solid fuels (coal). Municipal solid waste (MSW) can be used as refuse-derived fuel (RDF) using advanced pre-treatment. Pre-treatment is a way to set aside MSW material that cannot be used as energy such as glass, metal, chunks and other materials. In addition, it also serves as technology to reduce moisture content in waste. This study evaluated the potential of RDF as solid fuel in the Cement Industry. Two scenarios were tested to forecast RDF potential from 2015 to 2050 (35 years). The scenarios concerned Indonesia's regulations on 3R Program, MSW level of service, and variables of the waste composition. Since Indocement is located in Kabupaten (District) Bogor, Indonesia, the source of RDF is also generated in the area. Kabupaten Bogor produced MSW amounting to 1,787 tons/day in 2015, and each year it will increase along with the increasing growth of population. In 2015 , the energy required to produce 12.62 million tons of clinker amounted to 9.87 billion Mcal, whereas the available energy from RDF was 1.15 billion Mcal. After the year 2050, the energy required is projected to reach 34.51 billion Mcal to produce 25 million tons of clinker, while RDF energy available for that year will only be 1.73 billion McCall, so it is necessary to close the coal in the energy shortage. RDF energy generated in Kabupaten Bogor only meets 3-6\% of the energy required per year by the cement industry. It can be concluded that the use of RDF as fuel is not sufficient to cover the needs of energy in the cement industry. The need for supply in other cities in the form of MSW itself and/or solid waste meets the supply of energy in the cement industry. Receiving RDF from neighboring towns or setting up cooperation with nearby factories to process RDF can be a solution for energy shortage in the supply of RDF in Bogor.
\end{abstract}

Keywords - municipal solid waste; refuse-derived fuel; waste to energy; cement industry.

\section{INTRODUCTION}

The generation of solid waste is rapidly highly correlated from fast growing economic as well [1]. Waste has become an issue in Indonesia. In 2010, Indonesia was the fourth most populated country in the world has as many as 237.64 million inhabitants [2]. Hand in hand with massive population is the increasing amount of solid waste in large cities in Java including the Bogor regency as the sustainer of Jakarta, the capital of Indonesia. It was reported that the amount of solid waste in Bogor regency reached 1,787 tons/day. Indonesia has about 500 landfills which most of them are open dumping and almost reach full capacity limit [3].

In addition to the increasing waste generated in Indonesia especially in the city of Bogor, energy consumption in
Indonesia is also increasing. This phenomenon is shown in demand for coal in the country from January-June 2008 reaching 69.44 million tons [4]. Energy is an essential factor for a driving force for the development especially industry [5]. Almost 51.9\% of coal consumption was used for generating power, while more than $15.89 \%$ was for the industry, including the cement industry and the rest was exported $[4,6,7]$. Domestic needs of coal of over $70 \%$ result in a decreasing coal reserve in Indonesia. The Ministry of Energy and Mineral Resources Agency in 2016 issued that currently, Indonesia has 7.12 billion of coal resources and about 18.71 million tons of coal reserves in 2009. Consequently, Indonesia's coal reserves will be exhausted by the year 2112 [4], [7].

The Association of Indonesian Cement Manufacturers stated that cement consumption in Indonesia continues 
increasing as when consumption of cement reached 58.58 million tons per year in 2013 and went up to 62.09 million tons in 2014. Details of the cement consumption are presented in Fig. 1

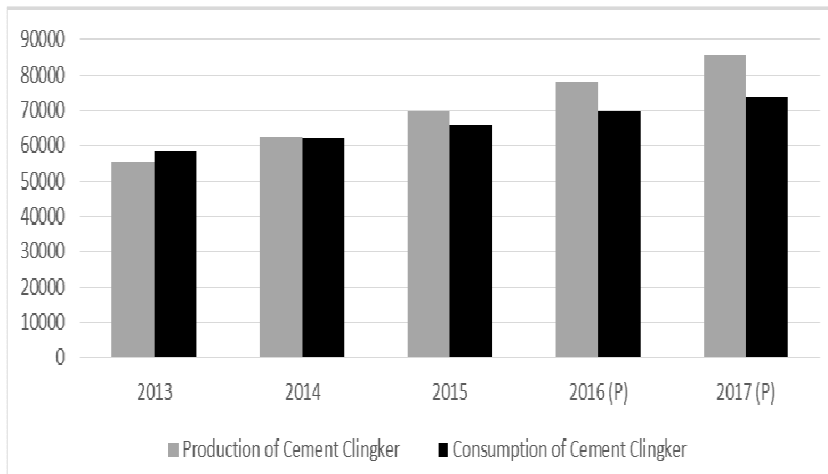

Fig 1. Cement production and consumption Indonesia [8]

During cement production, raw material must be dried and burned in order to produce cement. As the second largest cement industry in the world, Indocement Tbk. requires energy amounting to 2.3 million $\mathrm{MCal} /$ day to reach 4.672 tons of cement production per day. As coal used as the primary energy supply for their kiln, Indocement needs around 1500 tons of coal per day with coal heat value as much as $5200 \mathrm{kcal} / \mathrm{kg}$. The large needs compared to coal reserves Indocement Tbk. forces the company to look for other alternatives for energy to full-fill their needs for energy. They plan for these alternative sources of energy to meet the minimum requirement of $20 \%$ of the total heat needed during cement production [9]

Many studies found that Municipal Solid Waste (MSW) could be used as an alternative source of energy and processed to become Refused Derived Fuel (RDF) since their composition of combustible substances is similar to that in the composition such as paper, plastic, fabric etc. [10] [13]. After the processing, the calorific value of RDF can reach $3000 \mathrm{kcal} / \mathrm{kg}$ or more with a moisture content below $20 \%$ [14]. However, the composition of municipal solid waste (MSW) in Indonesia is heterogeneous with high moisture content; therefore, the solid waste cannot be used as it is as fuel. Other parameters such as particle size, chlorine and sulfur content and high water content require the solid waste produced in Indonesia to be pre-treated before becoming the RDF [15].

$\mathrm{RDF}$ potential as an alternative source of energy has been developed in several countries. In research [16], nonhazardous industrial waste is very advantageous economically and environmentally. Studies conducted in India revealed that utilizing municipal solid waste, as alternative energy would reduce land for landfills and the carbon footprint of the plant. Other research [17] claims that using RDF as fuel is environmentally friendlier compared to petroleum coke as fuel. Recent research [18] reports that mixing it with RDF petroleum coke as a fuel resulted from the combustion gas emissions burned in the rotary kiln unit still meets the threshold of quality standards meaning that RDF can be used as an alternative fuel.

TABLE II

TWO SCENARIO DEVELOPED IN THIS STUDY

\begin{tabular}{|c|c|c|c|c|c|c|c|c|c|c|c|c|c|c|c|}
\hline \multirow{3}{*}{ No } & \multirow{3}{*}{ Parameter } & \multicolumn{7}{|c|}{ Scenario 1} & \multicolumn{7}{|c|}{ Scenario 2} \\
\hline & & \multicolumn{14}{|c|}{ Period } \\
\hline & & 1 & 2 & 3 & 4 & 5 & 6 & 7 & 1 & 2 & 3 & 4 & 5 & 6 & 7 \\
\hline 1 & Population Projection & \multicolumn{7}{|c|}{ Arithmetic method } & \multicolumn{7}{|c|}{ Arithmetic method } \\
\hline 2 & GDP Projection & \multicolumn{7}{|c|}{ N/A } & \multicolumn{7}{|c|}{ N/A } \\
\hline 3 & $\begin{array}{l}\text { Domestic waste } \\
\text { generation } \\
\text { (Residential) } \\
\end{array}$ & \multicolumn{7}{|c|}{ 3L/person/day } & \multicolumn{7}{|c|}{ 3L/person/day } \\
\hline 5 & $\begin{array}{l}\text { Level of service for } \\
\text { domestic wastes }\end{array}$ & $75 \%$ & $75 \%$ & $77 \%$ & $77 \%$ & $79 \%$ & $79 \%$ & $81 \%$ & $75 \%$ & $75 \%$ & $75 \%$ & $75 \%$ & $75 \%$ & $75 \%$ & $75 \%$ \\
\hline 6 & $\begin{array}{l}\text { Non domestic waste } \\
\text { generated }\end{array}$ & \multicolumn{7}{|c|}{$0.05-2.75 \mathrm{~L} /$ person/day } & \multicolumn{7}{|c|}{$0.05-2.75 \mathrm{~L} /$ person/day } \\
\hline 7 & $\begin{array}{l}\text { Nondomestic waste } \\
\text { generation (Public } \\
\text { facility) }\end{array}$ & \multicolumn{7}{|c|}{ Based on population growth } & \multicolumn{7}{|c|}{ Based on population growth } \\
\hline 8 & $\begin{array}{l}\text { Level of service for } \\
\text { nondomestic wastes }\end{array}$ & $95 \%$ & $95 \%$ & $95 \%$ & $95 \%$ & $95 \%$ & $95 \%$ & $95 \%$ & $75 \%$ & $75 \%$ & $75 \%$ & $75 \%$ & $75 \%$ & $75 \%$ & $75 \%$ \\
\hline 9 & $\begin{array}{l}\text { Waste recycled, } \\
\text { reduced, and reuse } \\
(\text { Upstream) }\end{array}$ & $40 \%$ & $45 \%$ & $50 \%$ & $55 \%$ & $60 \%$ & $65 \%$ & $70 \%$ & $40 \%$ & $40 \%$ & $40 \%$ & $40 \%$ & $40 \%$ & $40 \%$ & $40 \%$ \\
\hline 10 & $\begin{array}{l}\text { Organic Composition } \\
\text { of wastes }\end{array}$ & $51 \%$ & $47 \%$ & $44 \%$ & $41 \%$ & $39 \%$ & $37 \%$ & $35 \%$ & $51 \%$ & $51 \%$ & $51 \%$ & $51 \%$ & $51 \%$ & $51 \%$ & $51 \%$ \\
\hline 11 & $\begin{array}{l}\text { Inorganic Composition } \\
\text { of wastes }\end{array}$ & $49 \%$ & $53 \%$ & $56 \%$ & $59 \%$ & $61 \%$ & $63 \%$ & $65 \%$ & $49 \%$ & $49 \%$ & $49 \%$ & $49 \%$ & $49 \%$ & $49 \%$ & $49 \%$ \\
\hline
\end{tabular}






Fig. 2 System boundary used in this study

Indocement Tunggal Prakarsa is a company located in Citeurep, Bogor regency, and West Java, Indonesia. It is around $30 \mathrm{~km}$ from Jakarta, the capital city of Indonesia. Over the last five years, MSW from Bogor regency has been mixed with coal and utilized as a source of energy. This study will evaluate the potential of solid waste produced in Bogor regency as a source of energy in the production of cement at Indocement Tbk. Two scenarios have been developed by considering several matters such as level of service of waste, government policy in solid waste management, and the change in waste composition. Based on these two scenarios, a recommendation is written for integrating solid waste management with the need for energy in the area.

\section{MATERIAL AND METHOD}

System boundary on this study in Bogor regency has a population of around 5,459,668 in 2015 and an average of $3.02 \%$ in the growth of population per year. Total waste generated in Bogor regency was 1,787 tons/day [19]. Having only one landfill located in Nambo and no available waste treatment, waste management becomes a very complicated issue.

In this study, two scenarios were developed (Table II). In both scenarios, municipal solid wastes are projected from 2015 to 2050 . The 35 years period is divided again into seven shorter periods consisting of 5 years each. During this period, each region in Indonesia should reduce, reuse, and recycle a minimum of $40 \%$ of the waste it generates [20]. In scenario 1 , the reduction, recycle, and recycle program (3R program) continue to increase by $5 \%$ in each period. On the other hand, the $3 \mathrm{R}$ program is constant throughout the period in the second scenario. In scenario 1 the level of service increases continuously from $75 \%$ in the first two periods to $77 \%$ in the third and fourth periods and finally reached $81 \%$ in 2050. However, in scenario 2 the level of service remains the same at $75 \%$. The boundary study was derived from the existing condition of waste management in Bogor regency.
Municipal Solid Wastes are collected in temporary collection stations and then sorted. The only a small fraction of wastes are collected and recycled such as plastic bottles, metals, and paper. Afterward, most of the wastes are transported to landfills. In this study, an alternative treatment as mechanical and biological treatment is developed to process the waste as RDF/SRF.

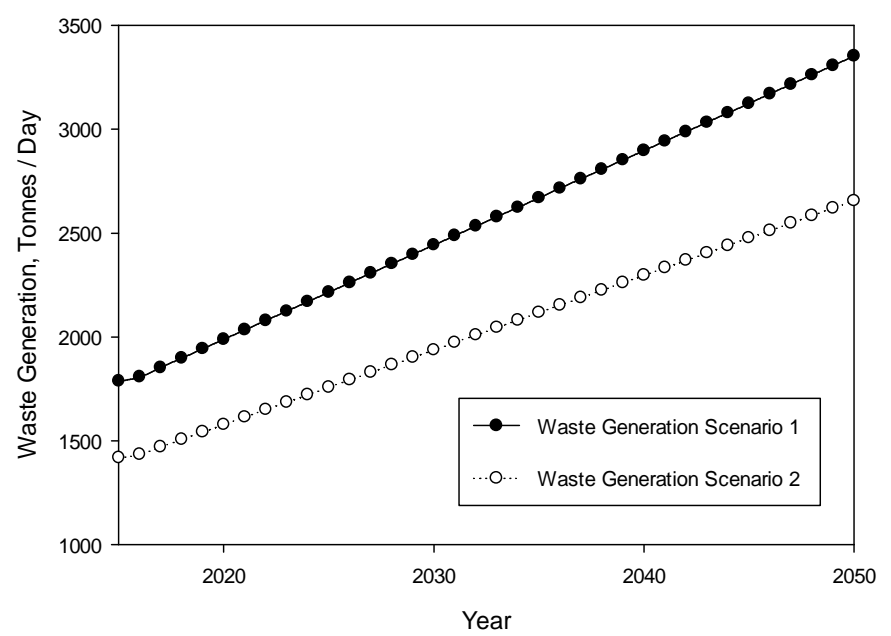

Fig. 3 Waste generation rate in scenario 1 and scenario 2

\section{RESULT AND DISCUSSION}

A. Availability of source of waste based on its quality and quantity

A critical factor for selecting a new source of energy is its sustainability, which is translated as the quantity and quality of waste to produce RDF that meets the standard. An example of a calculation to get the quantity of waste generated is presented in Table II, and more details are shown in Figure 3. 
TABLE III

AN EXAMPLE OF CALCULATION OF WASTE GENERATION FOR SCENARIO 2 IN 2015

\begin{tabular}{|c|c|c|}
\hline Parameter & Data & Note \\
\hline $\begin{array}{l}\text { Total Population } \\
\text { (A) }\end{array}$ & $5,459,668$ people & $\begin{array}{c}\text { Arithmetical } \\
\text { model with } \\
\text { growth rate of } \\
1,808 \%\end{array}$ \\
\hline $\begin{array}{l}\text { Waste generation } \\
\text { (B) }\end{array}$ & $3 \mathrm{~L} /$ person/day & $\begin{array}{c}\text { Indonesian } \\
\text { standard of SNI } \\
\text { S-04-1993-03 }\end{array}$ \\
\hline $\begin{array}{l}\text { Level of service } \\
\text { Domestic waste } \\
\text { (C) }\end{array}$ & $75 \%$ & \\
\hline $\begin{array}{c}\text { Domestic Waste } \\
\text { Collected }(\mathrm{D}=\mathrm{A} \times \\
\mathrm{B} \times \mathrm{C})\end{array}$ & 36.85 tons/day & $\begin{array}{c}\text { Solid waste } \\
\text { density } 300 \\
\mathrm{~kg} / \mathrm{m}^{3}\end{array}$ \\
\hline $\begin{array}{c}\text { Non-Domestic } \\
\text { Waste Generated } \\
(\mathrm{E}) \\
\end{array}$ & 1842.63 tons/day & \\
\hline $\begin{array}{c}\text { Level of Service } \\
\text { nondomestic waste } \\
(\mathrm{F})\end{array}$ & $75 \%$ & \\
\hline $\begin{array}{c}\text { Non-Domestic } \\
\text { Waste Collected } \\
(\mathrm{G}=\mathrm{E} \times \mathrm{F}) \\
\end{array}$ & 1381.98 tons/day & \\
\hline $\begin{array}{l}\text { Total Waste } \\
\text { generated in Bogor } \\
\text { regency }=\mathrm{D}+\mathrm{G}\end{array}$ & 1418.83 tons/day & \\
\hline
\end{tabular}

In scenario 1 , the rate of domestic waste generation in Bogor regency increased by an average of $1.834 \%$ / year for scenario 1and an average of $1.829 \%$ / year for scenario 2 . Stable waste generation in Bogor regency in 2015 amounted to $1,787.36$ tons/day and increased to 3351.67 tons/day in 2050. In scenario 2 , the service level is $75 \%$ and waste generation increased by an average of $1.829 \%$ / year. Waste generated in 2015 amounted to 1418.83 tons/day and reached 2656.22 tons/day in 2050 .

For the quality aspect, in 2015, the composition of the waste in Bogor regency was dominated by organic and inorganic waste by $50.84 \%$ and $49.16 \%$ respectively. The MSW proximate analysis is developed from the waste composition in Bogor regency. In scenario 1, the change in waste composition is because of the $3 \mathrm{R}$ program is applied in the temporary stations; however, lack of the $3 \mathrm{R}$ program does not lead to any changes in waste composition in scenario 2. The analysis of noncombustible, volatile solid and the moisture content of municipal waste in Bogor regency was conducted by using the proximate factors of each type of waste composition [15]. Proximate analysis aims at identifying the amount of waste that can be burned, the residues, and maximum calorific value of the RDF produced.

In scenario 1, moisture content in MSW is down gradually each year (Figure 4). A decrease of $1.98 \%$ in moisture content per year is due to the increasing amount of chemical waste compared to organic waste. An increase of $0.68 \%$ in volatile matter content per year is due to the increasing amount of mineral content that affect the higher volatile matter.

Contrary to the scenario 1 , the moisture content of MSW in scenario 2 increases at a rate of $1.78 \%$ / year. The volatile matter in scenario 2 has increased at a rate of $1.81 \% /$ year. The absence of $3 \mathrm{R}$ will increase the MSW composition such as plastic and paper, hence the increasing volatile matter.

\section{B. Energy requirement of cement production}

The cement production processes start from the mining, milling, drying, first firing, milling and packaging [8]. After that, mining, limestone, clay, and sand iron are mixed and heated at a high temperature in a kiln to produce clinker. Subsequently, clinker and gypsum are crushed and mixed to produce cement [21].

The kiln is an integral part of a cement production process. The process of drying and firing in the pre-heated process and rotary kiln requires a considerable amount of solid fuel in the process with a temperature above $18500 \mathrm{C}[22,23]$. The amount of energy reported to treat raw materials and produce cement is presented in Figure 6. The data were collected within 30 days from the 8 plant production units in Indocement Tbk. By converting coal consumption to be used in generating heat to produce, cement clinker from raw materials. On average, each rotary kiln requires $2,858,823.42$ Mcal / days to burn 8,283 tons/day of raw materials and produces an average of 4672.27 tons of cement clinker per day.

TABLE IV

THE DETAILED TARGET OF THE 3R PROGRAM FOR EACH WASTE COMPOSITION

\begin{tabular}{|c|c|c|c|c|c|c|c|c|c|}
\hline \multirow{2}{*}{$\begin{array}{c}\text { Waste } \\
\text { composition }\end{array}$} & \multicolumn{8}{|c|}{ Inorganics } & \multirow{2}{*}{ Organics } \\
\hline & Paper & Glass & Plastics & Metals & Textile & Rubber & Wood & Total & \\
\hline Percentage & $35,72 \%$ & $6,59 \%$ & $34,36 \%$ & $0,39 \%$ & $20,34 \%$ & $0,92 \%$ & $1,69 \%$ & $49,16 \%$ & $50,84 \%$ \\
\hline \multicolumn{10}{|c|}{ Scenario 1} \\
\hline $2015-2019$ & $40 \%$ & $50 \%$ & $20 \%$ & $80 \%$ & $20 \%$ & $20 \%$ & $0 \%$ & $40 \%$ & $50 \%$ \\
\hline $2020-2024$ & $50 \%$ & $55 \%$ & $25 \%$ & $85 \%$ & $25 \%$ & $25 \%$ & $0 \%$ & $45 \%$ & $55 \%$ \\
\hline $2025-2029$ & $55 \%$ & $70 \%$ & $30 \%$ & $85 \%$ & $30 \%$ & $30 \%$ & $0 \%$ & $50 \%$ & $60 \%$ \\
\hline $2030-2034$ & $60 \%$ & $75 \%$ & $30 \%$ & $90 \%$ & $55 \%$ & $55 \%$ & $0 \%$ & $55 \%$ & $65 \%$ \\
\hline 2035-2039 & $65 \%$ & $80 \%$ & $35 \%$ & $90 \%$ & $60 \%$ & $60 \%$ & $0 \%$ & $60 \%$ & $70 \%$ \\
\hline $2040-2044$ & $70 \%$ & $90 \%$ & $35 \%$ & $95 \%$ & $75 \%$ & $75 \%$ & $0 \%$ & $65 \%$ & $75 \%$ \\
\hline $2045-2050$ & $80 \%$ & $95 \%$ & $35 \%$ & $95 \%$ & $80 \%$ & $80 \%$ & $0 \%$ & $70 \%$ & $80 \%$ \\
\hline \multicolumn{10}{|c|}{ Scenario 2} \\
\hline $2015-2050$ & $40 \%$ & $75 \%$ & $20 \%$ & $90 \%$ & $15 \%$ & $15 \%$ & $0 \%$ & $40 \%$ & $50 \%$ \\
\hline
\end{tabular}


TABLE V

DETAILED EXAMPLE CALCULATION OF PROXIMATE ANALYSIS OF SCENARIO 2 IN 2015

\begin{tabular}{|c|c|c|c|c|c|}
\hline $\begin{array}{c}\text { Solid Waste } \\
\text { Composition }\end{array}$ & $\begin{array}{c}\text { Solid Waste } \\
\text { Quantity }^{*} \\
\text { (Tones/year) } \\
(\mathbf{A})\end{array}$ & $\begin{array}{c}\text { Moisture Content } \\
\text { (Tons) } \\
(\mathbf{B})\end{array}$ & $\begin{array}{c}\text { Dry weight* } \\
\text { (tons) } \\
(\mathbf{C}=\mathbf{A}-\mathbf{B})\end{array}$ & $\begin{array}{c}\text { Volatile Matter* } \\
\text { (tons) } \\
(\mathbf{D})\end{array}$ & $\begin{array}{c}\text { Non-Combustible }^{*} \\
\text { matter }^{*} \text { (tons) } \\
\text { (E = C-D) }\end{array}$ \\
\hline Organic & $131,643.42$ & $\mathrm{~A} \times 60 \%=728,186.46$ & $52,657.37$ & $\mathrm{C} \times 56 \%=29,698.75$ & $2,632.87$ \\
\hline Paper & $54,563.14$ & $\mathrm{~A} \times 10 \%=513,08.79$ & $48,997.70$ & $\mathrm{C} \times 76 \%=37,189.25$ & $2,645.88$ \\
\hline Plastic & $4,194.77$ & $\mathrm{~A} \times 0.2 \%=1,290.22$ & $69,835.10$ & $\mathrm{C} \times 96 \%=66,902.03$ & $1,396.70$ \\
\hline Leather & $69,975.05$ & $\mathrm{~A} \times 10 \%=4,0582.12$ & $39,617.31$ & $\mathrm{C} \times 66 \%=26,147.43$ & $2,575.13$ \\
\hline Rubber & 98.40 & $\mathrm{~A} \times 10 \%=1,826.20$ & $1,782.78$ & $\mathrm{C} \times 84 \%=1,495.75$ & 176.50 \\
\hline Wood & $44,019.24$ & $\mathrm{~A} \times 20 \%=7,925.45$ & $3,438.68$ & $\mathrm{C} \times 68 \%=2,341.74$ & 20.63 \\
\hline Total & $1,980.87$ & $831,119.24$ & $216,328.94$ & $163,774.96$ & $9,447.70$ \\
\hline
\end{tabular}

In Table VI, it shows the detailed calculation to obtain the ratio of the energy from RDF and coal required in processing raw materials into cement clinker. It is shown that 345.14 Mcal is needed for processing 1 ton of raw materials per day or 616.32 Mcal to produce 1 ton of cement clinker. If the coal calorific value is $5200 \mathrm{Mcal} /$ ton, it takes approximately 0.12 tons of coal to produce 1 ton of cement clinker per day.

The energy requirement for the cement production is calculated based on the cement production until 2050 (Figure 7). A detailed calculation was conducted using curve fit or R square with cement production data from 2005 to 2014. Projections obtained by linear equations with $\mathrm{R} 2=$ 0.822 . Projections are carried out until the year 2035 for Indocement Tbk that has a maximum production capacity of 25 million tons/year.

Increasing demand for cement also increases the needs for energy. Indocement as a multinational company in the field of cement production has a production capacity of 25 million tons per year. However, until 2014, the capacity went up to 12.3 million tons per year. With a projected cement production of about $3.29 \%$ per year, in the year 2036 Indocement reaches a maximum production capacity of 25 million tons per year. By calculating the ratio of energy per production period at 610.90 clinker Mcal/tonne clinker, for
35 years Indocement could produce cement clinker amounting to 859.58 million tons. It requires $526.01 \times 109$ Mcal of energy meaning that 101 million tons of coal over 35 years or could spend $0.84 \%$ of Indonesia's coal reserves only for the cement sector alone.

\section{The potential energy of $R D F$}

The potential energy of waste is determined based on the waste composition. The low heating values (LHVs) are calculated with $20 \%$ moisture as an assumption; for example with high heating value (HHV of RDF is 1.16 x 109 Mcal, so the LHV are $9.29 \times 108 \mathrm{Mcal})$. An example and detailed calculation of LHV and HHV of RDF for scenario 1 in 2015 are presented in Table VII, while Figure 8 shows the potential energy of RDF produced for scenario 1 and scenario 2. Figure 8 illustrates the energy potential of RDF from 2015 to 2050 with calculation in Table IV. In both scenarios, the resulting energy continues to increase, but for four of the first period or during the first 20 years, the energy generated from scenario 1 is higher than that in scenario 2 . In scenario 1 , the level of service during the four periods or the first 20 years is higher than in any other period in scenario

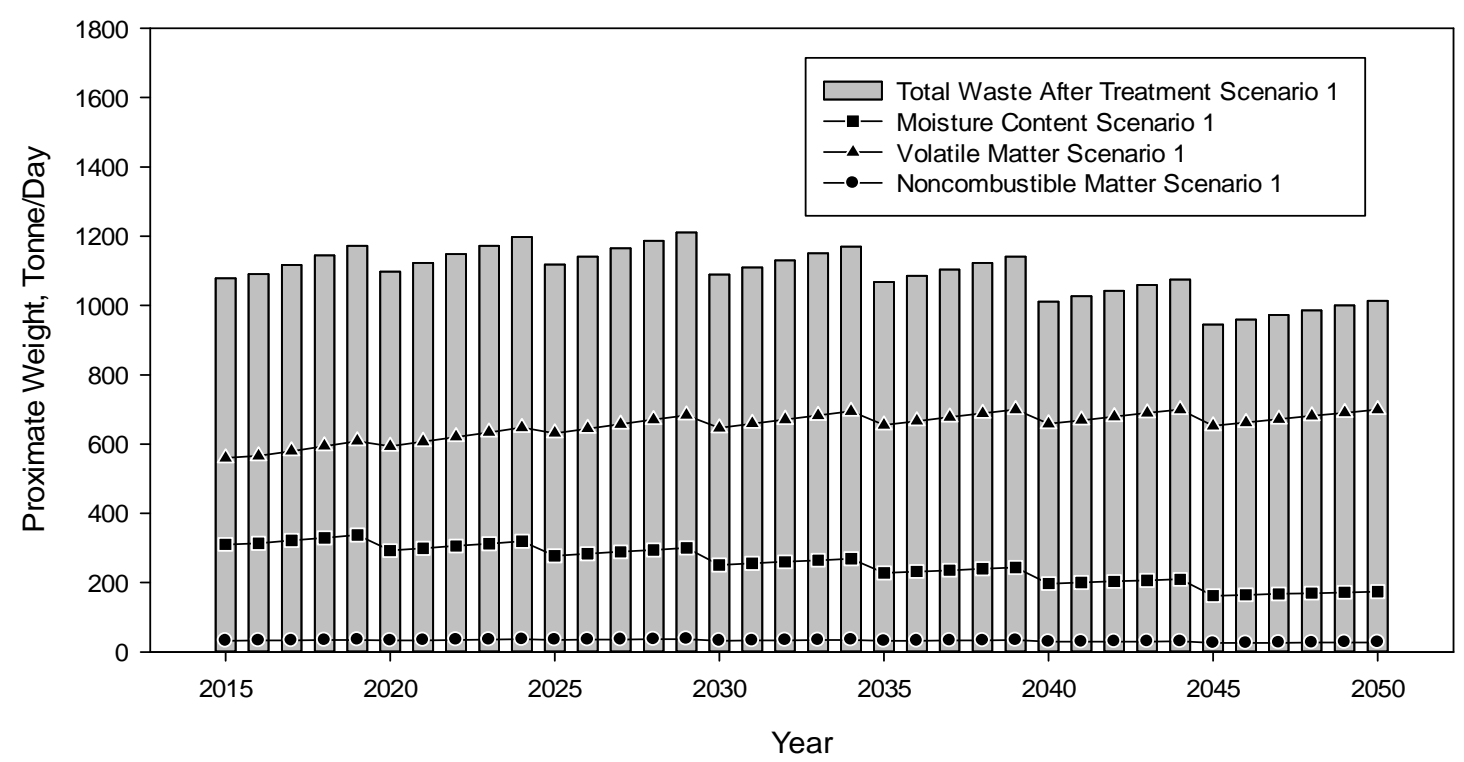

Fig. 3 Proximate analysis of waste generated in scenario 1 


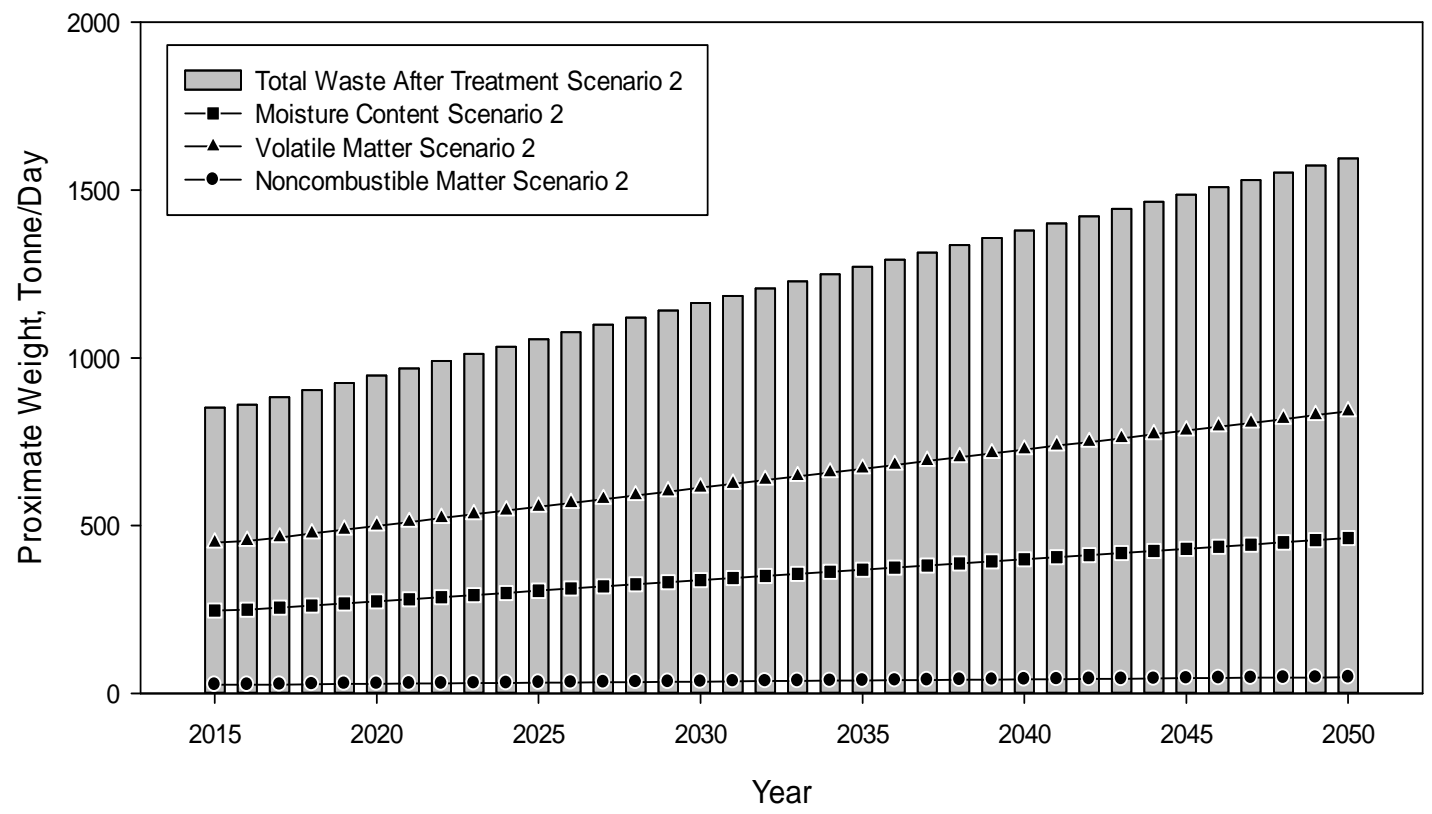

Fig. 4 Proximate analysis of waste generated in scenario 2

TABLE VI

THE RATIO OF HEAT TO BURNED RAW MATERIALS AND RAW MATERIALS TO CEMENT CLINKER

\begin{tabular}{|l|c|c|}
\hline \multicolumn{1}{|c|}{ Parameter } & Data & Unit \\
\hline $\begin{array}{l}\text { The average heat } \\
\text { needed during } \\
\text { the cement } \\
\text { clinker } \\
\text { production (A) }\end{array}$ & $2,858,823.42$ & Mcal/day \\
\hline $\begin{array}{l}\text { The cement raw } \\
\text { materials burned } \\
\text { (B) }\end{array}$ & $8,283.00$ & tons/day \\
\hline $\begin{array}{l}\text { Total cement } \\
\text { Clinker } \\
\text { production (C) }\end{array}$ & $4,672.27$ & tons/day \\
\hline $\begin{array}{l}\text { The ratio of } \\
\text { cement raw } \\
\text { materials to the } \\
\text { heat needed (D= }\end{array}$ & 345.14 & $\begin{array}{c}\text { Mcal /Tons of raw } \\
\text { materials per day }\end{array}$ \\
\hline $\begin{array}{l}\text { The ratio of raw } \\
\text { materials to } \\
\text { cement clinker } \\
\text { (E= C/B) }\end{array}$ & & $\begin{array}{c}\text { tons of cement } \\
\text { clinker/tons of raw } \\
\text { materials per day }\end{array}$ \\
\hline $\begin{array}{l}\text { Mass of coal } \\
\text { required (G= } \\
\text { D/Sp. Heat of } \\
\text { lignite coal) }\end{array}$ & 0.56 & $\begin{array}{c}\text { tons of coal /tons of } \\
\text { cement clinker per } \\
\text { day }\end{array}$ \\
\hline Not a Specic & & \\
\hline
\end{tabular}

Note: a Specific heat value of coal $=5200 \mathrm{Kcal} / \mathrm{kg}[9]$

However, in period 5,6 , and 7 , the energy in scenario 1 declines in waste composition changes and increases in the amount of waste that is recycled, and re-used. In order to know the amount of the RDF that can be used as coal substitute, it is assumed that all wastes generated in Bogor regency have been processed as RDF and use all as an alternative fuel. The ratio of the total amount of energy produced by the RDF per total energy needed for clinker productions is presented.

TABLE VII

AN EXAMPLE CALCULATION OF LHV AND HHV OF RDF FOR THE SCENARIO 1 IN 2015

\begin{tabular}{|c|c|c|c|c|}
\hline $\begin{array}{c}\text { Waste } \\
\text { Compo } \\
\text { sition }\end{array}$ & $\begin{array}{c}\text { Quantity } \\
\text { (tons } \\
\text { /year) }\end{array}$ & $\begin{array}{c}\text { Calorific } \\
\text { Value } \\
\text { (Mcal/to } \\
\text { ns) }\end{array}$ & $\begin{array}{c}\text { HHV } \\
\text { (Mcal/year) }\end{array}$ & $\begin{array}{l}\mathbf{L H V}^{\mathbf{d}} \\
\text { (Mcal } \\
\text { /year) }\end{array}$ \\
\hline Organic & $52,657.37$ & $3,32 ., 89$ & $1.75 \times 10^{08}$ & \\
\hline Paper & $48,997.70$ & $4,206.11$ & $2.06 \times 10^{08}$ & \\
\hline Plastic & $69,835.10$ & $7,994.45$ & $5.58 \times 10^{08}$ & \\
\hline Leather & $39,617.31$ & $4,913.33$ & $1.95 \times 10^{08}$ & \\
\hline Rubber & $17,82.78$ & $6,123.33$ & $1.09 \times 10^{07}$ & \\
\hline Wood & $34,38.68$ & $4,620.01$ & $1.59 \times 10^{07}$ & \\
\hline Total & $216,328.94$ & - & $1.16 \times 10^{09}$ & $9,29 \times 10^{08}$ \\
\hline
\end{tabular}

Note: Solid waste generated (Figure3)

${ }^{\mathrm{b}}$ Heating value of waste [15]

${ }^{\mathrm{c}}$ High Heating Value $=$ Waste quantity $\mathrm{x}$ calorific value [24]

${ }^{\mathrm{d}}$ Low Heating Value $=\mathrm{HHV} /(1 /(1-20 \%))[15-25]$

In Figure 9. The ratio of energy covered by coal is calculated by 1 - the ratio of energy from RDF per total energy needed. Figure 9 shows that the use of RDF from Bogor regency is not enough to cover the energy needs of the cement production at Indocement Tbk. The energy generated from RDF can replace an average of $4.89 \%$ and $4.55 \%$ respectively of the total energy needed for the production of cement clinker in scenario 1 and scenario 2 . For example, in 2015, $3.35 \times 106$ tons of coal is needed to produce $12.63 \times 106$ tons of cement clinker. By using all $269,450.43$ tons of RDF in scenario 1 and 216,328.94 tons of RDF in the scenario, 2,222,639.67-ton coal in scenario 1 and $178,594.94$ tons of coal in one year can be saved. The 
benefit of developing RDF from municipal solid wastes is clear. In the whole 35 years, The RDF could save more than 9.65 million tons of coal. In addition, the need of land for landfills which in 35 years could save $35.929 .181,39 \mathrm{~m} 3$ of landfill land for scenario 1 and $37.106 .065,38 \mathrm{~m} 3$ of landfill land for scenario 2 assuming a density of trash $300 \mathrm{~kg} / \mathrm{m} 3$, However, the use of RDF needs to be well developed since the process emits many air pollutants need controlling.

Reduce the use of land for landfills. Then, the regional landfill is needed to support RDF production since it is essential not only for managing waste in the cities but also for supporting energy for the industries. The nearest neighboring cities such as south and east of Jakarta could be an excellent alternative. With a population of around 2.62 million, South and East Jakarta potentially generate more than 5,597 tons/day of MSW [26].
On the other hand, Depok generated around 1350 tons of MSW per day. Indocement Tbk should consider another option. The company needs as well as create a solution to energy reduction by implementing energy efficiency by $1 \%$ each production year. To achieve such efficiency, it requires supporting utilities with rigorous treatment.

It is clear that the RDF from municipal waste generated in Bogor regency could only fulfill the small amount of the energy needs in Indocement Tbk. As Indocement Tbk. plans to increase their alternative fuel, it is recommended that other cities around participate in the development of RDF. Surrounding cities such as Jakarta, Depok, and Bogor can be an alternative to energy from waste. Having been sustained by these three cities shortage issue in alternative energy from waste can be solved and



Fig. 6 Energy needed for producing cement clinker from raw materials

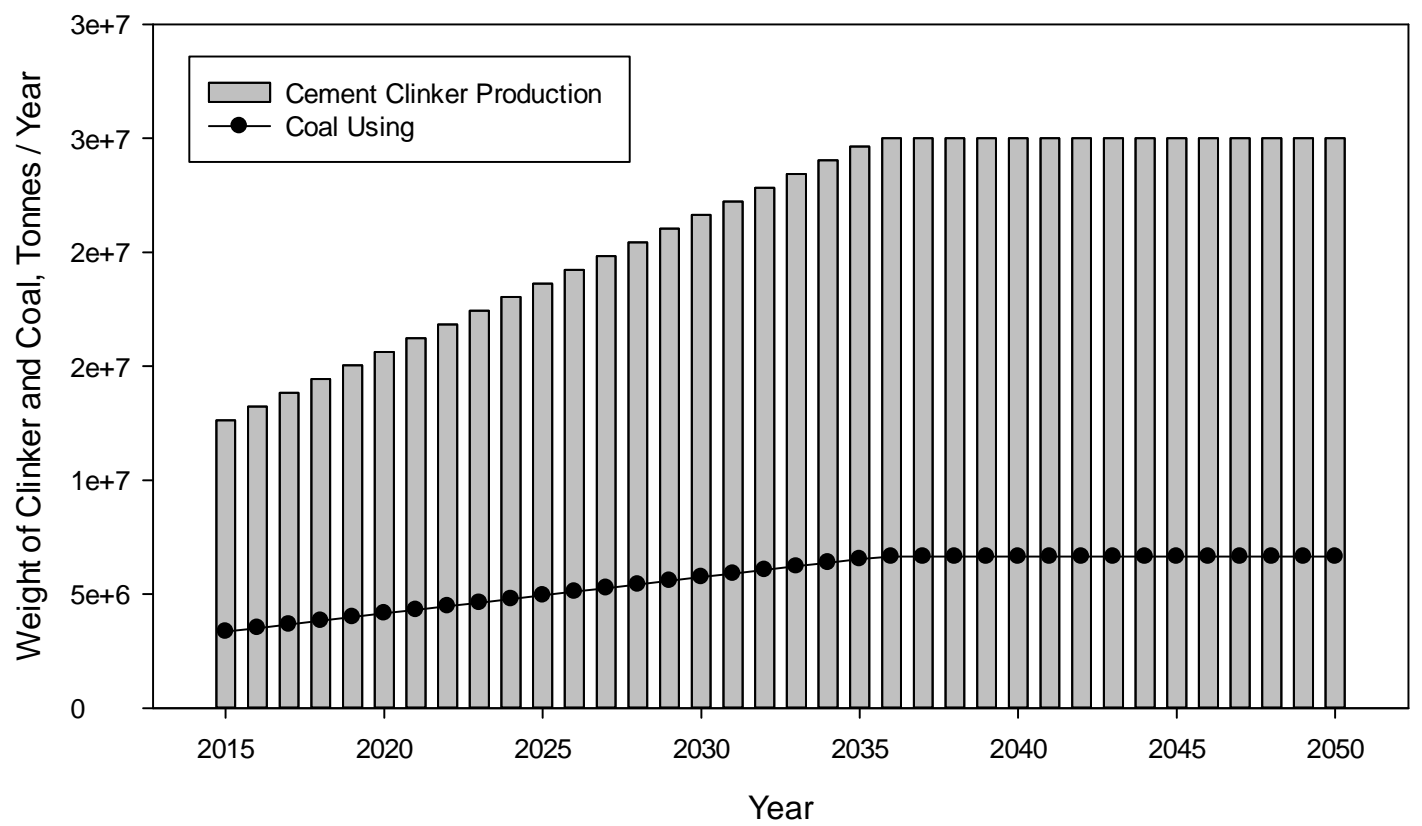

Fig. 7 Energy requirements for cement clinker production 


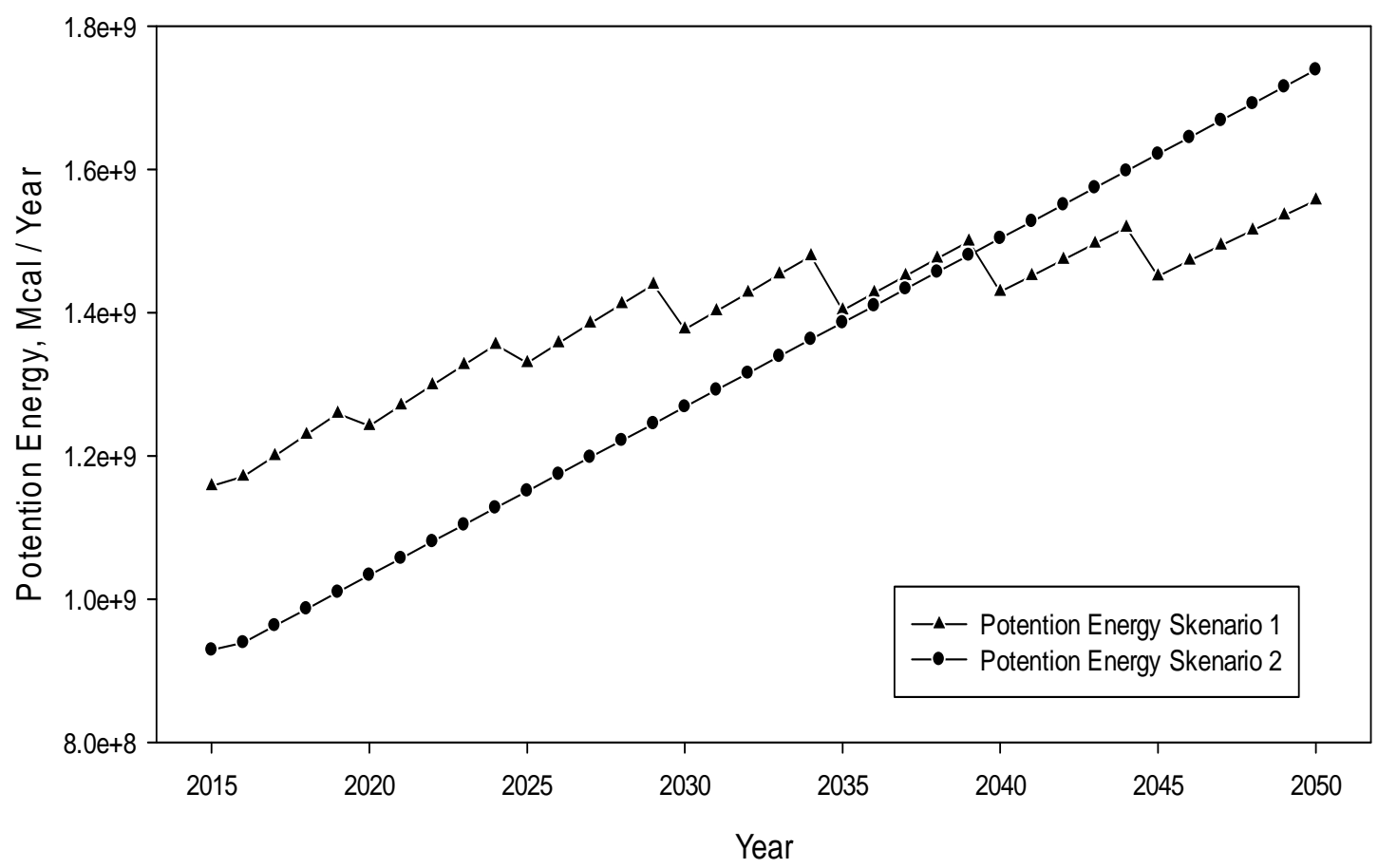

Fig. 8 Potential energy from RDF



Fig. 9 Percentage of energy covered by RDF in annual cement production

\section{CONCLUSION}

The use of MSW as RDF is handy to suppress the volume of MSW that will meet the landfill. In another hand, RDF sourced from Bogor regency is ineffective to meet the energy needs of the plant that is Indocement cement industry. Both scenarios will likely not be able to meet the energy needs of the cement industry. The energy generated from RDF can replace an average of $4.89 \%$ for scenario and $4.55 \%$ for scenario 2. RDF from Bogor district is still far from the target of $20 \%$ energy cover from waste. Cooperation from other cities as an RDF producer can potentially meet the energy needs for the production of cement. The regional landfill can be one of the solutions to deal with the limitations of the energy of just one town. An initiative of the company's energy to economize is also an alternative. With $1 \%$ of energy per year, the cement industry can save $5 \%$ of coal use for 35 years. Besides that, scenario 1 is more useful to produce energy than 
scenario 2. It is due to scenario 1 has a level of service and waste composition better than scenario.

\section{ACKNOWLEDGMENT}

The authors would like to acknowledge the funding of the present study, which was provided by Universitas Indonesia. In addition, we would like to thank Indocement Tunggal Prakarsa Tbk., particularly Angga Kusuma, for their support and laboratory analyses.

\section{REFERENCES}

[1] Iwan B., Chamhuri S. \& Hassan B., Current status of local stable waste generation in Malaysia, International Journal on Advanced Science Engineering Information Technology, Vol. 2(2012) No.2 ISSN: 20885334, 2012.

[2] National Central Bureau of statistics population, https://www.bps.go.id/id. Retrieved from https://sp2010.bps.go.id/, 2010

[3] Gabriel. A.Kristanto, Irma Gusniani, Aristiati Ratna. The Performance of Municipal Solid Waste Recycling Program in Depok, Indonesia. International Journal of Technology, Vol 6 No.2, 266-272, 2015.

[4] Ministry of energy and material resources, https://www.esdm.go.id/id. Retrieved from https://www.esdm.go.id/id/media-center/arsipberita/antisipasi-kebutuhan-batubara-dalam-negeri, 2016.

[5] Yoga P., Maharani D. S., \& Alfonsus A. R.., Production cost assessment of palm empty fruit bunch conversion to bio-oil via fast pyrolysis, International Journal on Advanced Science Engineering Information Technology, Vol. 4(2014) No.6 ISSN: 2088-5334, 2014

[6] Indonesia Investment Annual Report, www.indonesia-investments.com. Retrieved from http://www.indonesiainvestments.com/id/bisnis/komoditas/batu-bara/item236?: downloaded September 5th-2016

[7] Ministry of energy and material resources, https://www.esdm.go.id/id. Retrieved from https://www.esdm.go.id/id/media-center/arsipberita/sumber-daya-mineral-batubara-104760-juta-ton-emas-4250-tontembaga-68960-ribu-ton, 2016.

[8] Indonesia Cement Association, http://www.asi.or.id. Retrieved from http://www.asi.or.id/statis-11-statistic.html:,2011.

[9] Indocement Internal Annual Report, Indocement Tunggal Prakarsa Company Internal Reports, 2016.

[10] Abu-Qudais, M. and Abu-Qdais, H.A, A Review on energy saving strategies in the industrial sector. Renewable and Sustainable Reviews, 15(1): 68-150, 2011.
[11] Hwang, I., Nakajima, D., Matsuto, T., \& Sugimoto, T., Improving the quality of waste-derived char by removing ash. Waste Management 28, $424-434,2008$.

[12] Malkow, T., Novel and innovative pyrolysis and gasification technologies for energy efficient and environmentally sound MSW disposal. Waste Management 24, 53-79, 2004.

[13] Rigamonti, L. G., Life cycle assessment for optimizing the level of the separated collection in integrated MSW management systems. Waste Management 29, 934-944, 2009.

[14] Lee, P. F., Quantification of the Potential Energy From Residuals (EfR) in the UK. Energy From Waste, 2005.

[15] Tchobanoglous, G. T., Integrated Solid Waste Management: Engineering Principle and Management Issue. New York: McGraw Hill Inc, 1993.

[16] Rahul B., Sadhan K. G., and Ulhas V. P Co-processing of industrial waste in cement kiln - a robust system Co-processing of industrial waste in cement kiln - a robust system. The Tenth International Conference on Waste Management and Technology (ICWMT) (pp. 309-317). Mumbai: Elsevier, 2016.

[17] Güereca L.P., T. N.-L., The co-processing of municipal waste in a cement kiln in Mexico. Journal of cleaner production 107, 741-748, 2014.

[18] Kara, M., Environmental and economic advantages associated with the use of RDF in cement kilns. Resources, Conservation and Recycling 68, 21-28, 2012.

[19] Bogor Regency in Figure, Bogor Regency in Figure Annual Report. BPS Catalog: 1102001.3201, 2015.

[20] Departement of Public Works Indonesia, Pengembangan Pengelolaan Persampahan 2015. Kementerian Pekerjaan Umum dan Perumahan Rakyat Direktorat Jenderal Cipta Karya, 2014.

[21] Saidur R., M.S. Hossain, M.R. Islam, H. Fayaz, H.A. Mohammed, (2011). A review on kiln system modelling. Renewable and Sustainable Energy Reviews 15, 2011, 2487-2500.

[22] Abdelaziz EA, Saidur R and Mekhilef S, A review of energy saving strategies in the industrial sector. Renewable and Sustainable Energy Reviews 15, 150-68, 2011

[23] Abu-Qudais, M. and Abu-Qdais, H.A, A Review on energy saving strategies in the industrial sector. Renewable and Sustainable Reviews, 15(1): 68-150, 2011.

[24] Worrel, W., Solid Waste Engineering, Second Edition. United States of America: Global Engineering, 2012.

[25] Sadaka, S. V., Partial Composting for Biodrying Organic Materials. Agriculture and Natural Resources (FSA1055), 2011.

[26] Sanitation Department of Jakarta, http://data.jakarta.go.id Retrieved from

http://data.jakarta.go.id/dataset/jumlahproduksisampahdanterangkutper harimenurutkotaadmdkijakarta, 2015. 